\title{
Laws for the Anthropocene: Orientations, Encounters, Imaginaries
}

\author{
Kathleen Birrell ${ }^{1}$ - Daniel Matthews ${ }^{2}$
}

Accepted: 17 September 2020 / Published online: 13 October 2020

(c) Springer Nature B.V. 2020

This special issue is animated by questions arising from the ecological conundrums and challenges of our contemporary moment. While these questions have been peripherally engaged in critiques of political economy, with particular reference to intersections between ecology and empire, and more pointedly in ecofeminism and emergent and innovative scholarship in 'critical environmental law', the complex jurisprudential and political challenges posed by the climate crisis and ecological degradation have not been central to critical legal thought. This collection draws together a range of new critical perspectives on intersections between law and ecology.

The organising provocation for the special issue is the controversial Anthropocene thesis, which proposes the naming of a new geological epoch brought about by the practices and excesses of consumption, production and habitation. This thesis contends that the Holocene epoch, a period of recent climatic stability beginning at the close of the last ice age, has ended and we now find ourselves in a time of profound flux within the planetary climate system. The definitional and temporal boundaries of this new epoch remain contested, with the Anthropocene's proposed date of origin ranging from the early seventeenth century to the middle of the twentieth century (Lewis and Maslin 2018; Hamilton 2015; Davis and Todd 2017; Yusoff 2018). Many have critiqued or rejected the Anthropocene and the hierarchies implicit within its nomenclature, arguing that the concept posits a prematurely unified agent of change: a universalised and homogenised anthropos that must assume responsibility for climatic change, irrespective of the exclusionary demarcations and ecological harms perpetuated by capitalist and colonial social relations (Malm 2016; Malm and Hornborg 2014; Haraway 2016). As yet, the Anthropocene does not form part of the official Geologic Time Scale, as the details of this designation continue to

Kathleen Birrell

kbirrell@unimelb.edu.au

Daniel Matthews

danmat@hku.hk

1 Melbourne Law School, University of Melbourne, Carlton, VIC 3053, Australia

2 The University of Hong Kong, Hong Kong, Hong Kong SAR, China 
be debated within the fields of stratigraphy and Earth Systems Science. Nonetheless, the Anthropocene thesis offers a useful shorthand for the radicality of the current disruptions taking place within the planet's climate and ecology, and the term has enlivened a range of important interventions in the natural and social sciences, the arts and humanities (Crutzen 2002; Chakrabarty 2009; Turpin 2013; Latour 2017; Menley and Taylor 2017; DeLoughrey 2019).

The material and discursive implications of the Anthropocene are manifold, but our particular intervention is concerned with the articulation of laws for, rather than of, the Anthropocene. This distinction follows the orientation of decolonial theorisation and praxis toward and for plurality (Mignolo and Walsh 2018). The Anthropocene thesis has been variously interpreted, most frequently as a rehearsal and reinstantiation of imperial power and the inexorable pursuit of human mastery, instrumentalised in laws of the Anthropocene. In this special issue, we embrace an interpretation of our entry into a new climatic regime as a critical moment of generative disruption, in which epistemological plurality and multispecies relationality are acknowledged and expressed, in laws for the Anthropocene. Accordingly, the contributions to this issue explore ways in which the Anthropocene concept can provide opportunities to develop a radical critique of some of the coordinates of modern thought and the violent hierarchisations of empire, generate a more expansive and ecologically attuned critical jurisprudence, and cultivate a decolonising ethics of encounter between jurisprudential traditions. These concerns are elaborated through three related themes, which underpin the seven papers collected in this issue: orientations, encounters and imaginaries.

Orientations refers to both temporal and spatial situatedness and direction. Around which spatial categories should critical legal analysis orientate in the context of the Anthropocene: national territories, the planetary climate system as a whole, or more localised soils and terrains? What does it mean to understand (and critique) modern law with or in relation to 'deep' or 'geological' time? As Pottage argues, if, as some have claimed, the Anthropocene began in 1784-the year that James Watt patented the rotative steam engine-this new geological epoch is strangely entangled with the ethos and ideology expressed in patent law. Exploring these themes, Pottage brings the enchanted belief in continuous and inexhaustible innovation, underpinning the modern patent regime, into conversation with the material forces that have generated the Anthropocene. In a different mode, Moncrieff draws attention to the material legacies of harm generated by the corporate form and situates corporate responsibility within the new 'uncontained' horizon of history evoked by the Anthropocene thesis. Drawing on Latour's orientation toward the terrestrial as a response to the inadequacy of the local/global axis of modern thought, Yusoff's account of our 'originary mineralisation' as geologic subjects, and Watts's account of the mutual constitution of place and cognition in agentic materialities, Birrell and Matthews pursue a 're-storying' of modern law adequate to the temporal and spatial complexities revealed by the Anthropocene. This aims to resituate the abstract legal subject of liberal law in relationship with geologic and earthly forces and the web of obligations that sustain the habitability of place. The complexity of the bonds of and to place is emphasised by Wright, who focuses her discussion on the temporal disruptions enacted in an Aboriginal community garden in Armidale, New 
South Wales, Australia. She draws attention to the ways in which the 'poetic map' of performative rhythm enacted in ancestral and creation dances performed in the garden actively resists the linear maps and temporal homogeneity of colonisation. She dwells on a decolonial rendering of the garden as a rhythmic event, rather than a spatial configuration, made materially manifest through movement. The possessive spatiality of proprietary right is contrasted with a sonic rhythmicity, allowing a fluid patterning rather than a static partitioning of place.

Encounters refers to the meeting of distinct intellectual, legal or disciplinary approaches and the challenge of producing meaningful dialogue across and between traditions. This theme is taken up by Wright, and Birrell and Matthews, who foreground the development of dialogic rather than appropriative encounters between Indigenous and non-Indigenous epistemologies and jurisprudences. These papers approach decoloniality both in and as a form of praxis (Mignolo and Walsh 2018) and ground a dialogue between legal traditions in the relational and material reorientations prompted by the Anthropocene. In Burdon's contribution, this theme is engaged in a different way, by bringing the largely undervalued discourse of obligation into an encounter with prevailing rights discourses. Considering more recent applications of the rights frame to environmental harm, such as the attribution of rights to 'nature', environmental stewardship, and eco-constitutionalism, he argues that these approaches are circumscribed by extractive capitalism. Drawing on the work of Hans Jonas, Burdon proposes that the human agency central to the Anthropocene requires a reorientation not toward ecology but toward a revaluated human subject, and a moral responsibility enacted in the fulfilment of duty and obligation. De Lucia attends to further Anthropocenic encounters between law and ecology by eschewing dominant biopolitical governance regimes and instead embracing an aesthetics of wonder. Wonder is construed as itself a mode of encounter, navigating a constitutive relationality rather than negotiating engagements between separable entities. An encounter between seemingly divergent temporal registers is staged by Pottage when he brings patent jurisprudence into conversation with geological time, exemplified by the combustion and conversion of fossils into fuel within the patented mechanism of the rotative steam engine. This encounter between modes of appropriation enacts an Anthropocenic alchemy, whereby the time of priority in patent law is instrumentalised as property, and technological invention is abstracted from ecological materiality.

Imaginaries refers to questions of aesthetic, literary and performative representation, but also to modes through which social and ecological life are perceived and rendered meaningful. As Amitav Ghosh has described it, today's climate emergency is not simply an environmental disaster but also a crisis of culture and the imagination (Ghosh 2017). Laws are critical in this context. Dominant articulations of rights, duties and liabilities - as well as broader constitutional principles including popular sovereignty, territorial jurisdiction and citizenship - all play a key role in shaping the social imaginary, sensitising actors to social relations in a unique configuration that arguably obscures many of the challenges of climatic transformation. How might these legal imaginaries be reimagined for the Anthropocene? Grear reflects upon these dominant imaginaries, construed as a disembodied 'law of the Anthropocene', and instead proposes an embodied and lively imaginary of 'law/s for the 
Anthropocene'. Whereas the dominant legal imaginary of the Anthropocene turns upon the disembodied legal subject, the borders and disaggregated parts of which are defined by proprietorial right, Grear offers legal imaginaries for the Anthropocene. These imaginaries, she suggests, explore 'sympoietic normativities', which acknowledge the unbounded relationalities of, in Haraway's terms, 'making-with' (Haraway 2016, p. 58). Whereas modern law conventionally turns upon demarcation and distinction, Grear advocates an embrace of material and sensory multiplicity and connectivity. A different kind of engagement with the imaginary is offered by Moncrieff who opens her analysis with an interpretation of Brian Jungen's 'Cetology', a whalebone sculpture comprised of suspended plastic garden chairs. Exploring encounters between natural and commodity histories, Moncrieff is able to provocatively re-imagine the limitations of corporate self-governance. For De Lucia, in championing an aesthetics of wonder, the 'biopolitical coordinates' of modern law and of the legal subject are generatively reimagined. Wonder is here conceived as an irreducibly relational and sensory ontology — an ontology of contingency — as opposed to the material domination and instrumentalism of biopolitical governance. Adapting a natural law methodology, De Lucia's contribution presents an ontological framework for a legal imaginary for the Anthropocene, which is not ensnared within the aporia of biopolitics but emerges within social and ecological relations. In a similar vein, Wright contrasts different legal imaginaries, juxtaposing the appropriative impulses and cartographic materiality of 'settler' colonial law, articulated as proprietorial right, with the temporal dimensions of rhythmic Indigenous jurisprudential traditions, expressed in song and dance.

\section{Openings and Provocations}

Taken as a whole, this collection of essays argues that the Anthropocene thesis has radical and generative implications for critical legal scholarship. Beyond its technical designation in the earth sciences, the Anthropocene provokes contemplation of political narratives and social imaginaries that challenge some of the fundamental presuppositions of modernity, engendering renewed reflection on the ways in which agencies traverse the presumed dualisms between the biotic and abiotic, the human and non-human. This necessitates the development and rearticulation of ontologies and epistemologies that seek to understand how social life is situated within, rather than set against, a routinely othered 'nature'. The Anthropocene calls for a broad reassessment of some of the theories and frameworks that have prevailed within dominant accounts of law, rights, governance, sovereignty and the ordering of associative life. Central to the critical legal studies project has been the systematic critique of the ethical, ontological and epistemological foundations of modern law. Prevailing scholarship that draws on Marxist, feminist, deconstructive, critical race and post-colonial theories, however, tends to remain sociocentric in outlook, with the unique agencies and materialities described by ecology and geology featuring, if at all, as a mere 'backdrop' to the analysis. We contend that the ongoing climate crisis compels modes of analysis and argumentation that extend the existing coordinates 
of legal critique in order to situate law, legal concepts and institutions in the entangled sphere of relations that the Anthropocene has illuminated.

These are wide ranging challenges and provocations, which clearly cannot be addressed in a single volume. Indeed, our initial ambition for this project was for a more expansive collection of essays that drew on an even wider range of critical and interdisciplinary perspectives than those presented here. The disruptions caused by the coronavirus pandemic - an event that signals the ever tightening imbrication of human and non-human agencies and that is itself an indicator of our fragile ecological situation-made this impossible. This special issue provides a critical intervention into law and ecology, its breadth of engagement probing the disorienting implications of the Anthropocene concept, both rhetorical and material. Future research might be directed toward the more expansive scope we had originally envisaged, the importance of which is heightened by the zoonotic entanglements of the pandemic.

Prominent in the contributions featured here and critical to future analysis is a comprehension of the historical re-framings engendered by the Anthropocene, which extend beyond the history of capitalism to emphasise the ecological dimensions of empire (Ghosh 2017; Yusoff 2018). Imperial violence in its myriad forms is made manifest in calculated and cumulative ecological degradation and, in the extreme, ecocide. This history turns on the colonial logics of appropriation and accumulation, and the attendant stratification of suffering, both human and nonhuman. Locating this history in the material objects and embodied subjects of empire is instructive, generating a perspectival shift away from the imperial metropole and toward the putative periphery. This proliferation of perspectives refutes the 'supposed singularity' of Western modernity, and illuminates the complex 'genealogy of the carbon economy' (Ghosh 2017, pp. 103, 108). This genealogical complexity is explored in this issue, with some contributions considering the imbrication of private law and the production and legitimation of Anthropocenic harms. Drawing upon earlier critical legal studies traditions, which took the relation between law and political economy as a primary focus, further research might inquire into the intersections between the private law regimes that legitimate the contemporary extractive economy, the legacies of empire and settler colonialism, and the ecological transformations that are increasingly contouring social life.

More broadly, the acknowledgement of epistemic plurality and the ethics of intercultural encounter are central to the contributions to this special issue, particularly between Indigenous and non-Indigenous traditions. Extending these decolonial interventions, future work might consider different perspectives on ecological imperialism and historical entanglements between the human and nonhuman, and properly attend to that which Escobar describes as the "epistemic force of local histories' (2004, p. 217; Mignolo and Walsh 2018, p. 27). This historical pluralisation acknowledges the 'wake work' of imperialism (Sharpe 2016), a colonial history made manifest in present and imminent catastrophe, but also facilitates the resurgence of suppressed knowledges. These knowledges, cognised in dialogic encounters, resonate with the articulation of different forms of normativity, which both precede and exceed the modernist frame. Contributions to this issue suggest the recuperation and elaboration of various modes of non-anthropocentric normativity, which emphasise relational, rhythmic, aesthetic and sensory attachments and 
dependencies between different life forms. The challenges articulated here pose questions that move 'beyond critique' (Latour 2004), and compel us to not only apprehend the disorienting revelations of the Anthropocene but also to convert such disorientations into generative reorientations, which develop new theories and practices of community. Laws are critical to this project, reflective and productive of an ethics of relationality. The challenge and provocation of this special issue, and for future scholarship, is to envisage and enact laws for rather than of the Anthropocene, reimagining intersections between law and ecology that embrace a wondrous plurality.

\section{References}

Chakrabarty, Dipesh. 2009. The climate of history: Four theses. Critical Inquiry 35 (2): 197-222.

Crutzen, Paul. 2002. The geology of mankind. Nature 415 (6867): 23.

Davis, Heather, and Zoe Todd. 2017. On the importance of a date, or decolonizing the anthropocene. An International Journal for Critical Geographies 16 (4): 761-780.

DeLoughrey, Elizabeth. 2019. Allegories of the anthropocene. Durham: Duke University Press.

Escobar, Arturo. 2004. Beyond the third world: Imperial globality, global coloniality and anti-globalization social movements. Third World Quarterly 25 (1): 207-230.

Ghosh, Amitav. 2017. The great derangement: Climate change and the unthinkable. Chicago: Chicago University Press.

Hamilton, Clive. 2015. Getting the anthropocene so wrong. The Anthropocene Review 2 (2): 102-107.

Haraway, Donna J. 2016. Staying with the trouble: Making kin in the Chthulucene. Durham and London: Duke University Press.

Latour, Bruno. 2004. Why has critique run out of steam? From matters of fact to matters of concern. Critical Inquiry 30 (2): 225-248.

Latour, Bruno. 2017. Facing Gaia: Eight lectures on the new climatic regime. London: Polity.

Lewis, Simon L., and Mark A. Maslin. 2018. The human planet: How we created the Anthropocene. London: Penguin.

Malm, Andreas. 2016. Fossil capital: The rise of steam power and the birth of global warming. London: Verso.

Malm, Andreas, and Alf Hornborg. 2014. The geology of mankind? A critique of the Anthropocene narrative. Anthropocene Review 1 (1): 65-69.

Menley, Tobias, and Jesse Oak Taylor (eds.). 2017. Anthropocene reading: Literary history in geologic times. Pennsylvania: The State University of Pennsylvania Press.

Mignolo, Walter, and Catherine Walsh. 2018. On decoloniality: Concepts, analytics, praxis. Durham and London: Duke University Press.

Sharpe, Christina. 2016. In the wake: On blackness and being. Durham and London: Duke University Press.

Turpin, Etienne (ed.). 2013. Architecture in the anthropocene: Encounters among design, deep time, science and philosophy. Michigan: Open Humanities.

Yusoff, Kathryn. 2018. The anthropocene and geographies of geopower. In Handbook on the geographies of power, ed. Mat Coleman and Jon Agnew. London: Edward Elgar.

Publisher's Note Springer Nature remains neutral with regard to jurisdictional claims in published maps and institutional affiliations. 